\title{
The cost of excessive postoperative use of antimicrobials: the context of a public hospital
}

\section{Consequências do uso excessivo de antimicrobianos no pós-operatório: 0 contexto de um hospital público}

\author{
Rafael Santos Santana ${ }^{1}$; Ariane de Carvalho Viana²; Jozimário da Silva Santiago²; Michelle Santos Menezes²; Iza Maria Fraga \\ Lobo $^{3}$; Paulo Sergio Marcellini ${ }^{4}$
}

\section{A}

\begin{abstract}
Objective: To evaluate the improper use of antimicrobials during the postoperative period and its economic impact. Methods: We conducted a prospective cohort study by collecting data from medical records of 237 patients operated on between $01 /$ 11/08 and 31/12/08. Results: from the 237 patients with the information collected, 217 (91.56\%) received antimicrobials. During the postoperative period, 125 (57.7\%) patients received more than two antimicrobials. On average, $1.7 \pm 0.6$ antimicrobials were prescribed to patients, the most commonly prescribed antibiotic being cephalothin, in $41.5 \%$ (154) of cases. The direct cost of antimicrobial therapy accounted for $63.78 \%$ of all drug therapy, this large percentage being attributed in part to the extended antimicrobial prophylaxis. In the case of clean operations, where there was a mean duration of 5.2 days of antibiotics, antimicrobials represented $44.3 \%$ of the total therapy cost. Conclusion: The data illustrate the impact of overuse of antimicrobials, with questionable indications, creating situations that compromise patient safety and increasing costs in the assessed hospital.
\end{abstract}

Key words: Anti-infective agents. Drug utilization. Anti-bacterial agents/administration \& dosage. Health care costs. Economics, medical.

\section{INTRODUCTION}

In the hospital environment, antimicrobials are among the most prescribed drugs, accounting for $20-50 \%$ of drug expenditures ${ }^{1}$. Their rational use is defined as the practice of prescribing that results in the optimal indication, dosage, route of administration and duration of a therapeutic or prophylactic regimen, providing range of clinical success with minimal patient toxicity and low impact on microbial resistance ${ }^{2}$

The increase in bacterial resistance to various antimicrobial agents entails difficulties in individual therapeutic care and contributes to increased rates of hospital infections. The use of antibiotics must be judicious and restricted to some circumstances, as misuse could bring the following consequences: treatment or prophylaxis failure; adverse drug interactions; medication errors; and increased bacterial resistance to antimicrobials ${ }^{3-5}$. These issues are still directly related to the increased costs of treatment and, consequently, health spending.
According to Abrantes et al. ${ }^{6}$, apart from the clinical consequences, there is still a social and personal cost of inappropriate use of these drugs, which involves increasing the length of stay, days not worked, school absences, disability and death. Such implications justify efforts towards knowing and rationalizing the use of antimicrobials. Thus, rectifying the situation is today one of the most complex challenges in the health care reform ${ }^{7}$.

A surgical site infection is an important health problem. It is estimated that in the U.S. 23 million operations are performed annually, with the development of at least 920,000 wound infections ${ }^{8}$. One of the alternatives to minimize this problem is the use of antimicrobials.

Antimicrobial use in the perioperative period, despite accepted as an adjuvant in prevention of infectious disease, has not shown the expected large impact. Rather, there was an increase in some cases of surgical wound infection, besides the emergence of resistant strains. However, programs that improved the use of antibiotic prophylaxis demonstrated reduced incidence of infections in clean operations, from $5.1 \%$ to $0.8 \%$, in potentially

1. Post-Graduation Program in Pharmaceutical Sciences, Universidade de Brasilia - UNB; 2. Departamento de Assistência Farmacêutica Secretaria de Ciência e Tecnologia e Insumos Estratégicos/MS, Brazil; 3. Hospital Universitário da Universidade Federal de Sergipe - UFS; 4. Universidade Federal do Estado do Rio de Janeiro - UNIRIO. 
contaminated ones, from $10.1 \%$ to $1.3 \%$, and in contaminated ones, from $21.9 \%$ to $10.2 \%$. Though simple, prophylaxis is often inadequate, particularly regarding the early use of antibiotics, the repetition of doses during surgery, and especially its prolonged postoperative use ${ }^{9}$.

Systematic reviews ${ }^{10,11}$ have shown that the extension of prophylactic doses of antibiotics and the use of antibiotic association most often do not cause any individual benefit to patients of surgical specialties, increasing hospital costs and exposing users to unnecessary risks.

The indiscriminate use of this therapeutic class of drugs, coupled with the great capacity of adaptation of microorganisms, enables the emergence of resistant strains, which requires, in turn, research and synthesis of increasingly expensive drugs, resulting in significant increases in healthcare costs. Due to the great interest of antimicrobials in all the welfare spending, particularly in highly complex institutions, programs of control and rational use of antimicrobials intend to reduce the direct costs of these drugs and their side costs related to the development of multidrug resistance, such as increases time and costs of hospitalization, use of tests and procedures of greater complexity and admittance to intensive care units 12,13.

This study aimed to evaluate the appropriateness of antimicrobials use and its economic impact during the postoperative period.

\section{METHODS}

We conducted a prospective, uncontrolled, cohort study, which examined the use of antimicrobials for patients who were hospitalized in postoperative wards of the Sergipe Emergency Hospital, a large hospital admitting patients exclusively from the Public National Health System.

We followed all patients who underwent a surgical procedure, were transferred and hospitalized for at least 48 hours in the postoperative wards in the period between November $1^{\text {st }}$ and December $31^{\text {st }}, 2008$. Data were collected from patient's records and transcribed to a form designed for this research, with items composed of closed, pre-coded questions, and open ones, which were coded later.

The study protocol was approved by the Ethics in Research Committee of the Sergipe State Department of Health. The purposes of the study and its methodology were informed to the Commission of Hospital Infection Control (CHIC) and Service of Pharmaceutical Assistance of the hospital, including the commitment to data confidentiality.

The variables studied were related to the epidemiology and treatment parameters of the study population: age, gender, diagnosis, length of hospitalization, potential contamination of the wound, parameters based on the Program of Infection Control ${ }^{14}$, antimicrobials used, time of antimicrobials use, drug interactions, interruptions in the therapeutic regimen and direct costs of antimicrobial therapy by type of operation, which included only the values of purchasing the drugs, the spending on ancillary materials (syringes, catheters, diluent) not being accounted, nor any expenditure on human resources and maintenance of the place of admittance. For encoding of the target drugs, we used the Anatomical Therapeutic Chemical Classification - ATC - model ${ }^{15}$, while for the diseases, the International Statistical Classification of Diseases and Related Health Problems - ICD-10 ${ }^{16}$

We considered a "break in therapeutic regimen" when there were any discrepancy between what was prescribed and what was administered, which resulted in lack of administration or interruption of at least one dose of the drug. For evaluation of drug interactions, we used the Micromedex data base as reference ${ }^{17}$. We evaluated frequency and proportion of the collected data in descriptive statistics.

\section{RESULTS}

We followed 237 patients, with an average stay of about nine days, minimum of two and maximum of 58 . Of these, $180(75 \%)$ were male. The mean age of patients was 39 years, ranging between 12 and 85 . We observed that $68.2 \%$ of diagnoses were for categories S, T and X, defined as "injury, poisoning and consequences of external causes".

Of the 237 patients enrolled in the study, 217 (91.56\%) made use of antimicrobial postoperatively, with a mean of $1.709 \pm 0.6$ medications per patient.

The total direct cost of employed drug therapies in the followed patients represented an amount of $\mathrm{R} \$ 33,545.49$, the antimicrobial therapy accounting for approximately $64 \%$ of this value $(R \$ 21,395.86)$.

In the hospital where this study was conducted, the antimicrobial commonly used in surgical prophylaxis was cephalothin. The most commonly prescribed medications during the postoperative period were: cephalothin $41.5 \%$, gentamicin $15 \%$ and clindamycin $12.9 \%$ (Table 1).

As to the classification of operations for potential contamination of the incision described in the records, we observed an increased number of surgical procedures classified as potentially contaminated $24 \%$ (57), as contaminated and $20.5 \%$ (48) of cases (Table 2 ). There was no such information in $24 \%$ of records evaluated. The notification of wound infection detection, as well as its prognosis, were also not observed conducts.

During hospitalization, drug interaction occurred in 23\% (89) of 371 antimicrobial prescriptions (Table 3). Of the interactions, $89.9 \%$ (80) were classified as pharmacodynamic of greater severity. It was observed that $57(26.2 \%)$ patients had break in therapeutic regimen sometime during hospital stay. 


\section{DISCUSSION}

Most patients, $91.56 \%$, made use of antimicrobials during the postoperative period, which shows a widespread use of this therapeutic tool in the study target hospital.

Today, there is no doubt about the conceptual validity of restricting the use of antibiotics as a strategy to control the emergence of bacterial resistance, whose control is related to reduction of cost, adverse events, and especially mortality ${ }^{18}$

Approximately 30 to $50 \%$ of antimicrobials used in hospitals are intended for surgical prophylaxis, the rate of inappropriate use in these cases being estimated at 30 to $90 \%{ }^{19}$. According to the Guidelines for Prevention of Nosocomial Infection proposed by the Brazilian Society of Infectious Diseases ${ }^{20}$, antibiotic use in surgical prophylaxis should have parenteral presentation, minimal toxicity and cost, be a weak inducer of resistance and possess activity against most pathogens causing surgical site infection in the institution. For the Consensus of Rational Use of Antimicrobial Agents ${ }^{21}$, first-generation cephalosporins are the antimicrobials with the nearest profile and must be the choice for most surgical specialties.

the available alternatives in the study hospital, we found that the most commonly used drug, cephalothin, is in accordance with the recommendations of the Brazilian Society of Infectious Diseases ${ }^{20}$ and of the Ministry of Health ${ }^{21}$, for it is a first generation cephalosporin. However, both references indicate cefazolin, not available in the institution during the study, as the best alternative for having longer half-life (two hours), thus covering operations of up to 3-4 hours duration. Cephalothin has a shorter half life (28 minutes), forcing the re-use every two hours of operation. Besides greater intraoperative safety, the use of cefazolin instead of cephalothin is better from the economics point of view. According to data available on the Ministry of Health price database ${ }^{22}$, the average cost of cephalothin for the system public hospitals is around $\mathrm{R} \$ 0.96$, while cefazolin costs on average $\mathrm{R} \$ 1.24$. Since the repetition time of cephalothin dosage is twice that of cefazolin, it would be a saving of approximately $35 \%$ if the second therapeutic option was opted for.

Antimicrobial prophylaxis in surgery is defined as the use of antimicrobials for preventing surgical site infections ${ }^{21}$. After finishing the procedure, the contamination of the operative site is rare, though not impossible. Therefore, in theory, additional doses of antibiotics would not be indicated ${ }^{23}$. We observed in this study that the prolonged use of the same antibiotic used in prophylaxis is a common conduct.

Although there is no record of infection diagnosis in the medical records, the average time of use of cephalothin after surgery was $6.32 \pm 4.6$ days. The mean duration of antimicrobials in general was $6.6 \pm 5.6$ days. Even in operations deemed "clean", the average use of antibiotics was $5.2 \pm 4.1$ days (Table 2 ). Only seven (15.5\%) patients who underwent surgical procedures considered clean were not given postoperative antimicrobials. This prolonged use of antimicrobials in clean operations accounted for $44.33 \%(R \$ 1,803.07)$ of the direct costs of medical treatment.

It is known that prolonged antibiotic use beyond the duration of the surgical procedure adds no benefit to the therapy, however causing an increase in the costs of prophylaxis and possibly the risk of developing bacterial resistance. It is accepted also that the use of prophylaxis is not indicated in many types of surgery, especially in so-called clean operations and in those in which there is not a perforated hollow viscus or need for prosthesis placement ${ }^{24}$.

Table 1 - Proportion of drugs prescribed and their mean time of use.

\begin{tabular}{lrr}
\hline Drug & $\%$ & Mean time of use \\
\hline Cephalothin1g & $6.3 \pm 4.6$ \\
Gentamicin 80mg & 41.5 & $6.6 \pm 5.7$ \\
Clindamycin 600mg & 15.0 & $7.2 \pm 6.5$ \\
Metronidazole 40mg/ml & 12.9 & $4.1 \pm 2.7$ \\
Ciprofloxacin 400mg & 8.62 & $6.7 \pm 3.8$ \\
Ceftriaxone 1g & 8.62 & $8.2 \pm 8.2$ \\
Cephalexin 500mg & 5.60 & $9.6 \pm 6.5$ \\
Cefepime 2g & 2.15 & $10.3 \pm 4.9$ \\
Vancomycin 500mg & 1.60 & $7.0 \pm 4.3$ \\
Ertapenem 1000mg & 1.36 & $8.5 \pm 4.9$ \\
Imipenem 500mg+Cilastatin 500mg & 1.07 & $9.0 \pm 3.5$ \\
Cefotaxime 1g & 0.80 & $3.0 \pm 0.0$ \\
Ciprofloxacin 500mg & 0.26 & $7.0 \pm 0.0$ \\
Sulfa 400mg+ Trimethropim 80mg & 0.26 & $10.0 \pm 0.0$ \\
\hline
\end{tabular}


Table 2 - Proportion of operations, average usage time and total direct cost of antimicrobial therapy.

\begin{tabular}{lrccr}
\hline Type of operation* & $\%$ & $\begin{array}{c}\text { Average usage } \\
\text { time }\end{array}$ & $\begin{array}{c}\text { Average cost of } \\
\text { antimicrobial }\end{array}$ & $\begin{array}{c}\text { Total cost of antimicrobial } \\
\text { therapy }\end{array}$ \\
\hline Clean & 19 & $5.2 \pm 4.1$ & $\mathrm{R} \$ 40.06$ & $\mathrm{R} \$ 1.803 .07$ \\
Potentially Contaminated & 24 & $6.1 \pm 4.7$ & $\mathrm{R} \$ 22.48$ & $\mathrm{R} \$ 1.259 .11$ \\
Contaminated & 20.5 & $7.8 \pm 5.6$ & $\mathrm{R} \$ 157.82$ & $\mathrm{R} \$ 7.575 .42$ \\
Infected & 12.5 & $4.5 \pm 1.9$ & $\mathrm{R} \$ 235.45$ & $\mathrm{R} \$ 7.063 .69$ \\
Not informed & 24 & $7.9 \pm 6.8$ & $\mathrm{R} \$ 64.81$ & $\mathrm{R} \$ 3.694 .57$ \\
Total & 100 & $6.6 \pm 5.6$ & $\mathrm{R} \$ 90.27$ & $\mathrm{R} \$ 21.395 .86$
\end{tabular}

* Classification of potential risk of contamination (Decree 2626/98 Ministry of Health).

Table 3 - Time of antimicrobial use, exposure to potential risks related to the use of these medications, and costs.

\begin{tabular}{|c|c|c|c|c|}
\hline Time of ATM Use* & ATM* ${ }^{*}$ prescription & Discontinuation (\%) & $\mathrm{DI}^{+}(\%)$ & Average Cost / Day \\
\hline Up to 3 days & 116 & $(17.1)$ & $(14.6)$ & $\mathrm{R} \$ 11.65$ \\
\hline From 3 to 10 days & 193 & $(19.2)$ & $(25.9)$ & $\mathrm{R} \$ 13.21$ \\
\hline Above to 10 days & 62 & $(40.3)$ & $(35.4)$ & $\mathrm{R} \$ 18.49$ \\
\hline Total & 371 & $(22.1)$ & $(23.9)$ & $\mathrm{R} \$ 15.28$ \\
\hline
\end{tabular}

* ATM: Antimicrobial; + DI: Drug Interaction

We observed that the prevalence of use of two or more medications during the study period represented $57.7 \%$ (125) of the cases. Similar data in audits of surgical wards showed prevalence of antimicrobial polytherapy in $53 \%$ of patients ${ }^{25}$. Monotherapy for antibiotic prophylaxis or treatment of infection is considered as an ideal situation from the point of view of rational use and the prescriber must be objective. Although there are indications for combination therapy, its excessive use in clinical practice is frequent, without support of protocols, with increased exposure of the patient to medication errors ${ }^{26,27}$.

The so-called "polypharmacy" or multiple drug consumption is one of the main risk factors associated with the prevalence of drug interactions in prescriptions. The main interaction was found in the records between cephalothin and gentamicin, in $86.5 \%$ (77) of interactions with antimicrobial agents. This combination is associated with nephrotoxic effect. A randomized, double-blinded study in septic patients showed a higher incidence of nephrotoxicity with combined use of gentamicin with cephalothin ${ }^{28}$.

Another serious problem detected was breaking of the treatment regimen of patients followed, observed in $26 \%$ during the study. Strict control of schedules, the dilutions and the intervals between doses of antibiotics is necessary so as the effect between the maximum peak and minimum level action required for bacterial killing be the expected for effective treatment, preventing selection of resistant organisms ${ }^{28}$. Causes of discontinuation were quantified and categorized as flaws in the prescribing process, $31.9 \%$ of the cases, which include constant changes of different attending physicians and failure to fill the CHIC assessment report, with the resulting unauthorized dispatch of the drug by the pharmacy; flaws in the nursing process (56\%) comprising omission of administration of any dose, initial administration with subsequent interruption of antimicrobials in patients without or refused $\mathrm{CHIC}$ report assessment; and the pharmaceutical supply failures (12.1\%) that include shortages of drugs during the period. Medication errors compromise patient safety and quality of care, as they are associated with increased morbidity and mortality, length of stay and health care costs and are responsible for $78 \%$ of severe iatrogenic conditions 29,30 .

The extension of antimicrobials use beyond the surgical period tends to bring an increase in risk to the patient and also increases the costs of assistance ${ }^{31}$. When the time of use of these drugs for less than three days is compared with the cases of longer periods, there is a proportional increase in the number of drug interactions (14.6\% to $35.4 \%)$, breaks in therapeutic regimen $(17.1 \%$ to $40.3 \%$ ) and a $58 \%$ increased in the average cost ( $R \$ 11.65$ to $R \$ 18.49$ ).

From the above, it is possible to illustrate the damage caused by failures in the use of antimicrobials in patients undergoing surgical treatment. From the individual point of view, it was noted that extensive use of antibiotics was associated with users' exposure to a greater number of drug interactions and undue breaks in therapeutic regimen. From the collective point of view, there was a direct association with increased direct costs of care. Other 
complications related to the indiscriminate use of these drugs, such as adverse reactions, microbial resistance, prolonged hospitalization or increased indirect costs, could not be observed and can be the target of further work.

\title{
R E S U M O
}

\begin{abstract}
Objetivo: avaliar o emprego de antimicrobianos relacionado ao seu uso inadequado e impacto econômico durante o período pósoperatório. Métodos: foi desenvolvido um estudo de coorte prospectivo por meio da coleta de dados de 237 prontuários de pacientes operados entre 01/11/08 e 31/12/08. Resultados: dos 237 pacientes com informações coletadas no estudo 217 (91,56\%) fizeram uso de antimicrobianos. Durante o pós-operatório, 125 (57,7\%) pacientes utilizaram mais de dois antimicrobianos. Foi prescrito, em média, 1,7 \pm 0,6 antimicrobianos por paciente, sendo o antimicrobiano mais prescrito a cefalotina, em 41,5\% (154) dos casos. O custo direto da terapia antimicrobiana representou $63,78 \%$ de toda a terapia farmacológica, sendo esta grande porcentagem atribuída em parte ao prolongamento da profilaxia antimicrobiana. No caso das operações limpas, onde houve um tempo médio de uso de antimicrobianos de 5,2 dias, os gastos com antimicrobianos representaram 44,3\% do custo total da terapia. Conclusão: os dados exemplificam o impacto do uso excessivo de antimicrobianos, com indicações questionáveis e criando situações que comprometem a segurança dos pacientes e aumento os custos no hospital avaliado.
\end{abstract}

Descritores: Anti-infecciosos. Uso de medicamentos. Antibacterianos/administração \& dosagem. Custos de cuidados de saúde. Economia médica.

\section{REFERENCES}

1. Louro E, Lieber NSR, Ribeiro E. Eventos adversos a antimicrobianos em pacientes internados em um hospital universitário. Rev Saúde Pública. 2007;41(6):1042-48.

2. Dellit TH, Owens RC, McGowan JE. Infectious Disease Society of America and the Society for Healthcare Epidemiology of America Guidelines for developing an Institutional program to enhance antimicrobial stewardship. Clin Infec Dis. 2007;44(2):159-77.

3. Tavares W. Antibióticos e quimioterápicos para o clínico. Rio de Janeiro: Atheneu; 2009.

4. Oliveira WL, Branco AB. Avaliação da antibioticoterapia em pacientes internados no Hospital Regional do Guará - DF. Comun ciênc saúde. 2007;18(2):107-15.

5. Holloway K, Green T. Drug and therapeutics committees? A practical guide. Genebra: WHO; 2003.

6. Abrantes PM, Magalhães SMS, Acúrcio FA, Sakurai E. Avaliação da qualidade das prescrições de antimicrobianos dispensadas em unidades públicas de saúde de Belo Horizonte, Minas Gerais, Brasil, 2002. Cad Saúde Pública. 2007;23(1):95-104

7. Management Sciences for Health. Rational Pharmaceutical Management Plus 2007 [acessado em novembro de 2012]. Disponível em: http://www.msh.org/projects/rpmplus/

8. Kluytmans J. Surgical infections including burns. In: Wenzel PR, editor. Prevention and control of nosocomial infections. Baltimore: Williams and Wilkins; 1997. p. 841-65.

9. Dias MBS, Torggler F. Padronização da profilaxia antimicrobiana no período peri-operatório. In: Comitê de Implementação de Diretrizes Assistenciais do Hospital Sírio-Libanês. Diretrizes Assistenciais do Hospital Sírio-Libanês. Rio de Janeiro: HSL; 2005.

10. William GJ, Geert WHIM. Antibiotic prophylaxis for surgery for proximal femoral and other closed long bone fractures. Cochrane Database Syst Rev. 2010;(3):CD000244.

11. Nelson RL, Glenny AM, Song F. Antimicrobial prophylaxis for colorectal surgery. Cochrane Database Syst Rev. 2009; (1):CD001181.

12. Dellit TH, Owens RC, McGowan JE Jr, Gerding DN, Weinstein RA, Burke JP, et al. Infectious Diseases Society of America and the Society for Healthcare Epidemiology of America guidelines for developing an institutional program to enhance antimicrobial stewardship. Clin Infect Dis. 2007:44(2):159-77.

13. Silva EU. A importância do controle da prescrição de antimicrobianos em hospitais para melhoria da qualidade, redu- ção de custos e controle da resistência bacteriana. Pratica Hospitalar. 2008;10(57):101-6.

14. Brasil. Ministério da Saúde. Portaria n 2616, de 12 de maio de 1998. Expede na forma de anexos às diretrizes e normas para prevenção e controle das infecções hospitalares. Diário Oficial da União, Brasília, DF, Seção 1, p.133; 1998.

15. World Health Organization Collaborating Centre for Drug Statistics Methodologhy. Guideline for ATC classification and DDD assignment 2010. Oslo: WHO; 2009

16. Classificação Estatística Internacional de Doenças e Problemas relacionados à Saúde. $10^{a}$ revisão (Cid 10).

17. Klasco RK, editor. DRUGDEX System [Database on the Internet] Greenwood Village (Colorado): Thomson MICROMEDEX; 1974 2012. Acessado em dezembro de 2011. Disponível em: http:// www.periodicos.capes.gov.br

18. Camargo LFA. Controle de antibióticos: mais que retórica, necessidade baseada em evidências. Einstein. 2003;1:135-6.

19. Munckhof W. Antibiotics for surgicals prophylaxis. Aust Presc 2005:28:38-40

20. Machado A, Ferraz AAB, Ferraz E, Arruda E, Nobre J, Konkewicz LR, et al. Prevenção da Infecção Hospitalar. In: AMB, CFM. Projeto Diretrizes. Acessado em: dezembro de 2012. Disponível em: http:/ /www.projetodiretrizes.org.br/projeto_diretrizes/065.pdf

21. Brasil. Ministério da Saúde. Agência Nacional de Vigilância Sanitária. A profilaxia antimicrobiana é feita em cirurgia? In: Brasil. Ministério da Saúde. Consenso Sobre o Uso Racional de Antimicrobianos. Brasília: Ministério da Saúde, 1998. p.27-31.

22. Brasil. Ministério da Saúde. Banco de preços em saúde. [acessado em 2009 Nov 29]. Disponível em: http://bpreco.saude.gov.br/ bprefd/owa/consulta.inicio

23. Hoefel R, Vidotti CCF, Menezes ES, Pinheiro S. Ações que estimulam o uso racional de antimicrobianos. Bol Farmacot. 2006;11(4):14.

24. Caldeira L, Teixeira I, Vieira I, Marques FB, Santiago LM, Rodrigues $V$, et al. Monitorização do consumo de antibióticos: nos serviços de cirurgia e de ortopedia de seis hospitais. Acta Med Port. 2006;19(1):55-66.

25. Souza HP, Vilhordo DW, Breigeiron R, Alessandretti MB, Dotti $E$ Silva TGB. Auditoria no uso de antimicrobianos em enfermaria cirúrgica. Rev Col Bras Cir. 2008;35(4):216-20.

26. Fuchs FD, Wannmacher L. Farmacologia clínica: fundamentos da terapêutica racional. $4^{\text {a }}$ ed. Rio de Janeiro: Guanabara Koogan; 2010. 
27. Brasil. Ministério da Saúde. Agencia Nacional de Vigilância Sanitária. Protocolo de segurança na prescrição, uso e administração de Medicamentos. Acessado em abril de 2014. Disponível em http:// www.anvisa.gov.br/hotsite/segurancadopaciente

28. Gosselin RA, Roberts I, Gillespie WJ. Antibiotics for preventing infection in open limb fractures. Cochrane Database Syst Rev. 2004;(1):CD003764.

29. Rothschild JM, Landrigan CP, Cronin JW, Kaushal R, Lockley SW, Burdick E, et al. The Critical Care Safety Study: The incidence and nature of adverse events and serious medical errors in intensive care. Crit Care Med. 2005;33(8):1694-700.

30. Wannmacher L. Erros: evitar o evitável. Uso Racional de Medicamentos: Temas Selecionados. 2005;2(7):1-6.
31. Marques TC, Reis A, Silva A, Gimenes F, Optz S, Teixeira T, et al. Erros de administração de antimicrobianos identificados em estudo multicêntrico brasileiro. Rev Bras Ciênc Farm. 2008;44(2):305314.

Received on 21/01/2013

Accepted for publication 23/03/2013

Conflict of interest: none.

Source of funding: none.

Address for correspondence:

Rafael Santos Santana

E-mail: rafaels.santana1@gmail.com 